\title{
The Pathogenesis of Fungal-Related Diseases and Allergies in the African Population: The State of the Evidence and Knowledge Gaps
}

\author{
Lorraine Tsitsi Pfavayi ${ }^{a}$ b Elopy Nimele Sibanda ${ }^{c-e}$ Francisca Mutapi ${ }^{\text {b, e }}$ \\ a Nuffield Department of Medicine, Centre for Tropical Medicine and Global Health, University of Oxford, \\ Old Road Campus, Oxford, UK; ${ }^{b}$ Institute of Immunology and Infection Research, University of Edinburgh, \\ Ashworth Laboratories, King's Buildings, Edinburgh, UK; ' ${ }^{\mathrm{C}}$ Asthma Allergy and Immunology Clinic, Twin Palms \\ Medical Centre, Harare, Zimbabwe; ${ }^{d}$ Department of Pathology, National University of Science and Technology

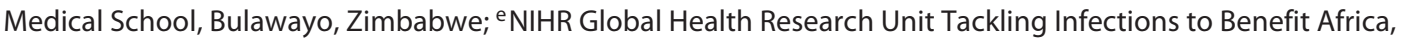 \\ University of Edinburgh, Ashworth Laboratories, King's Buildings, Edinburgh, UK
}

\section{Keywords}

Allergy · Fungi · Africa · Fungal diseases · Pathogenesis

\begin{abstract}
The prevalence of allergic diseases in the African continent has received limited attention with the allergic diseases due to fungal allergens being among the least studied. This lead to the opinion being that the prevalence of allergic disease is low in Africa. Recent reports from different African countries indicate that this is not the case as allergic conditions are common and some; particularly those due to fungal allergens are increasing in prevalence. Thus, there is need to understand both the aetiology and pathogenies of these diseases, particularly the neglected fungal allergic diseases. This review addresses currently available knowledge of fungal-induced allergy, disease pathogenesis comparing findings from human versus experimental mouse studies of fungal allergy. The review discusses the potential role of the gut mycobiome and the extent to which this is relevant to fungal allergy, diagnosis and human health.
\end{abstract}

Edited by: H.-U. Simon, Bern. (c) 2020 S. Karger AG, Basel

\section{KARGER}

karger@karger.com

www.karger.com/iaa

\section{Introduction}

Fungi are eukaryotic, filamentous and mostly sporeforming organisms that are ubiquitous in nature [1-3]. They are important disease-causing agents either directly as exemplified by cryptococcal meningitis [4], pneumocystis pneumonia [5], pulmonary aspergillosis [6-8] or indirectly as allergens that can induce or exacerbate respiratory diseases such as asthma [9].

Fungi are responsible for considerable morbidity as they cause a wide variety of diseases ranging from superficial skin mycoses [10-12] to potentially fatal systemic mycoses $[13,14]$. Annual global mortality due to fungal diseases is estimated to be over 1.6 million $[15,16]$. In Africa, tinea capitis dominates the overall burden with an estimated 8.6 million [17] affected in Ethiopia, Ghana [18] and South Africa [17, 19]. Despite this, the association between fungal pathogenesis and the adverse health sequelae remains poorly characterised partly because it frequently develops in patients with multiple morbidities including immunodeficiency [20,21].

In the last decade, there has been an increase in the incidence of fungal diseases $[22,23]$. The increase has partly been attributed to climate change with global warming 
believed to favour the propagation of fungal spores [22, 24]. Although fungi are a common and integral part of ecosystems, the impact of fungal diseases on the entire ecosystem can be devastating [7, 25-27]. Thus, fungi are considered a current and future public health problem that should not be underestimated [28].

\section{Public Health Burden of Fungal-Related Diseases}

The global prevalence of skin infections due to fungal infestation is estimated to be over a billion $[7,29]$ with an age-standardised disability-adjusted life year rate of 48.9 per 100,000 sixteen times less than that of malaria (794.7 per 100,000) [30]. More than 100 million people are said to be affected with mucosal fungal infections [16], whilst $>10$ million people succumb to severe allergies and a million die due to fungal infections [6]. As of 2017, global mortality owing to fungal infections was greater than that for malaria [31] and was equivalent to that for tuberculosis $[16,32]$. The public health impact of this relatively silent cause of morbidity and mortality has not been adequately addressed.

In Africa, the precise prevalence of fungal diseases is currently unknown; however, the very large number of HIV [33] and pulmonary tuberculosis cases in most African countries leads to a large number of cases of opportunistic fungal infections [17]. These fungal infections have been observed in most African countries in studies carried out by the Global Action Fund for Fungal Infections $[17,34]$. In Senegal, Nigeria, Malawi and South Africa, $12.5,11.8,7.54$ and $7.1 \%$ [19, 35-37] of the populations respectively are estimated to suffer from serious fungal diseases each year. These infections include chronic pulmonary aspergillosis $[18,19,35]$, pneumocystis pneumonia $[18,36,38]$, cryptococcal meningitis $[19,39$, 40], allergic bronchopulmonary aspergillosis (ABPA) $[35,40,41]$ and recurrent vulvovaginal candidiasis [4042]. However, the epidemiology of allergic diseases due to fungi exposure such as asthma and allergic rhinitis has not been fully elucidated [43]. This review focuses on immune-mediated fungal diseases.

\section{Prevalence of the Immune-Mediated Fungal Diseases in African Populations}

Allergy was thought to be rare in Africa in line with the hygiene hypothesis $[44,45]$ until the results of the International Study of Asthma and Allergies in Childhood, which showed an increase in the prevalence of allergic asthma, rhinitis and eczema in African countries [46-49]. Reports from different African countries indicate that allergic conditions are common [50-52]. However, there have been limited reports of allergy due to fungal allergens in the continent due to inadequate reporting, limited awareness and diagnostics [53, 54].

Recently, Kwizera et al. [55] carried out a systematic review and meta-analysis to estimate the burden of fungal asthma in Africa using data from cross-sectional studies and review articles. The data were obtained from 13 African countries, and this showed the average prevalence of fungal asthma as $28 \%$. These results show that fungal asthma is a significant problem in Africa, but there is still a dearth of epidemiological data in most countries [55].

From previous studies in parts of sub-Saharan Africa, the prevalence of fungal sensitisation was high, being $14.9 \%$ [50], 53\% [56] and 28\% [57] amongst referral patients in Zimbabwe, South Africa and Botswana, respectively. The patients included in these studies were secondary referrals, so only those with severe symptoms that warranted specialist consultation and had the financial capacity to afford specialist care were included. Consequently, it is likely that the cost barriers meant only a small proportion of affected individuals were captured in the studies.

The optimum conditions for fungal spore growth are in the range of $12-30^{\circ} \mathrm{C}$ [58], but some fungi species can tolerate lower or higher temperatures [22]. This climatic criteria encompass the majority of the African countries located in the subtropical zone, providing an optimum environment for fungal survival and growth [59, 60]. Hence, the data presented in these studies are likely to be an underestimation of the true extent of fungal sensitisation in sub-Saharan Africa.

\section{Types of Immune-Mediated Fungal Diseases}

The spectrum of immune-mediated fungal diseases is huge, and a number of these diseases have been widely studied $[61,62]$. The main diseases that affect individuals are allergic rhinitis [63], allergic conjunctivitis, allergic fungal sinusitis [64], atopic dermatitis [65] and asthma [66]. Other less common immune-mediated diseases are allergic bronchopulmonary mycoses (ABPM) [67] and hypersensitivity pneumonitis (HP) [68]. These are briefly discussed. 


\section{Allergic Rhinitis}

Allergic rhinitis is a common inflammatory disease of the nose $[62,69,70]$. It affects up to $40 \%$ of the population in Europe and the States [71]. Exposure to fungi/dampness has been associated with allergic rhinitis in epidemiological studies $[63,72]$. In a longitudinal populationbased study, Shaaban et al. [73] found that the presence of allergic rhinitis significantly increases the probability of adult-onset asthma [74].

\section{Allergic Conjuctivitis}

Allergic conjunctivitis is an inflammatory disease of the conjunctiva $[75,76]$. It affects $15-40 \%$ of the population [75] and maybe associated with allergic rhinitis [72]. Symptoms of allergic conjunctivitis are usually aggravated by exposure to dry and windy climates [77].

\section{Atopic Dermatitis}

Atopic dermatitis is a chronic inflammatory skin disease characterised by pruritic skin lesion $[78,79]$. Atopic dermatitis usually starts in early childhood and is frequently associated with allergic rhinoconjuctivitis and allergic asthma [65]. Most atopic dermatitis patients have been shown to be sensitised to the fungi Malassezia [80].

The small size of fungal spores $(<10 \mu \mathrm{m})[81,82]$ enable fungi to penetrate the bronchi, which may lead to allergic reactions of the lower respiratory tract resulting in allergic asthma, ABPM and allergic alveolitis [82].

\section{Allergic Bronchopulmonary Mycoses}

ABPM is a rare hypersensitivity disease of the lower airways characterised by sensitisation to fungi [83]. ABPM occurs in susceptible individuals with asthma and cystic fibrosis [84]. The most frequent ABPM is caused by Aspergillus fumigatus antigens and is commonly known as ABPA [85]. The pathogenesis of ABPA is characterised by colonisation of fungi in the lower airways and combines elements of Type I, III and IV hypersensitivity reactions [86].

\section{Allergic Fungal Sinusitis}

Allergic fungal sinusitis is a severe form of chronic rhinosinusitis in which individuals develop an intense inflammatory reaction to airborne fungi [87]. The pathogenesis is characterised by eosinophil-predominant Type I hypersensitivity reaction sustained by fungal antigens in the mucosa of the sinonasal tract in atopic individuals $[64,88]$.

\section{Hypersensitivity Pneumonitis}

$\mathrm{HP}$ also known as extrinsic allergic alveolitis [89] is an immunologically mediated lung disease, which predominantly occurs as an occupational disease [90]. The pathogenesis of HP is characterised by Type III and IV hypersensitivity reactions [68].

\section{Allergic Asthma}

Allergic asthma is an inflammatory disease of the airways characterised by bronchial hyperresponsiveness and airflow limitations [91, 92]. Fungal sensitisation maybe associated with severe asthma attacks requiring hospital admission [93]. Although the evidence that fungi can act as an asthma trigger is widely accepted, the mechanisms by which this occurs are still not clear [94, 95], nor has it been conclusively proven that fungi exposure is responsible for these clinical manifestations [96].

While effective therapies for controlling allergic reactions are available, none are curative. Consequently, allergic diseases such as asthma often persist from early childhood through to adulthood $[97,98]$. Such allergies usually have a detrimental effect on the quality of life of the affected individual and have been known to affect their sleep, competencies at work or school as well as their social interaction [99].

\section{Auto-Allergic and Autoimmune Conditions}

Fungi contribute to auto-reactivity against self-antigens due to shared epitopes between fungal and human proteins [61] such as manganese superoxide dismutase [100], thioredoxin, cyclophins and acid ribosomal proteins. The underlying mechanism is thought to be molecular mimicry $[61,101]$ maintaining severe chronic allergic diseases such as atopic dermatitis [102].

Int Arch Allergy Immunol 2020;181:257-269 
Table 1. Species-specific allergens

\begin{tabular}{|c|c|c|c|c|}
\hline $\begin{array}{l}\text { Allergen source } \\
\text { (species) }\end{array}$ & Allergen & $\begin{array}{l}\text { Molecular weight } \\
\text { range, } \mathrm{kDa}\end{array}$ & Protein family & References \\
\hline $\begin{array}{l}\text { Alternaria } \\
\text { alternata }\end{array}$ & $\begin{array}{l}\text { Alt a } 15^{*} \\
\text { Alt a } 10^{*} ; \text { Alt a } 8^{*} \\
\text { Alt a } 4^{*} \\
\text { Alt a } 7^{*} \\
\text { Alt a } 1^{*}\end{array}$ & $\begin{array}{l}50-58 \\
28-53 \\
57 \\
22 \\
11-45\end{array}$ & $\begin{array}{l}\text { Serine proteases } \\
\text { Dehydrogenases } \\
\text { Disulfide isomerases } \\
\text { Flavodoxins } \\
\text { Unknown }\end{array}$ & $\begin{array}{l}{[1]} \\
{[2,3]} \\
{[2,4]} \\
{[2,4]} \\
{[2,5]}\end{array}$ \\
\hline $\begin{array}{l}\text { Aspergillus } \\
\text { fumigatus }\end{array}$ & $\begin{array}{l}\text { Asp f } 23^{*} \\
\text { Asp f } 17^{*} \\
\text { Asp f } 34^{*} \\
\text { Asp f } 10^{*} \\
\text { Asp f } 15^{*} \\
\text { Asp f } 9^{*} \\
\text { Asp f } 5^{*} \\
\text { Asp f } 2^{*} \\
\text { Asp f } 1^{*} \\
\text { Asp f } 4^{*} ; \text { Asp f } 7^{*}\end{array}$ & $\begin{array}{l}44 \\
19.42 \\
19-20 \\
34-35 \\
15-16 \\
33.7 \\
42-43 \\
34-37 \\
16-18 \\
11-45\end{array}$ & $\begin{array}{l}\text { Ribosomal proteins } \\
\text { Galactomanno proteins } \\
\text { Cellwall proteins } \\
\text { Aspartic proteases } \\
\text { Cerato platanins } \\
\text { Glycosyl hydrolases } \\
\text { Metallo proteases } \\
\text { Fibrinogen-binding proteins } \\
\text { Ribonucleases } \\
\text { Unknown }\end{array}$ & $\begin{array}{l}{[6]} \\
{[6]} \\
{[7]} \\
{[6,8]} \\
{[6]} \\
{[6,9]} \\
{[6]} \\
{[6]} \\
{[4]} \\
{[6]}\end{array}$ \\
\hline $\begin{array}{l}\text { Cladosporium } \\
\text { herbarum }\end{array}$ & $\begin{array}{l}\text { Cla h } 9^{*} \\
\text { Cla h } 8^{*} \text {; Cla h } 10^{*} \\
\text { Cla h } 7^{*} \\
\text { Cla h HCh1 } \\
\text { Cla h2 }\end{array}$ & $\begin{array}{l}50-58 \\
28-53 \\
22 \\
10.5 \\
11-45\end{array}$ & $\begin{array}{l}\text { Serine proteases } \\
\text { Dehydrogenases } \\
\text { Flavodoxins } \\
\text { Hydrophobins } \\
\text { Unknown }\end{array}$ & $\begin{array}{l}{[1]} \\
{[2,3,10]} \\
{[2]} \\
{[11]} \\
{[5]}\end{array}$ \\
\hline
\end{tabular}

* These allergens have been approved by the WHO/IUIS Allergen Nomenclature Committee [12]. All the other allergens can also be found in the Allergome database [13].

WHO/IUIS, World Health Organization and International Union of Immunological Societies.

Currently, the evidence for fungal exposure being linked to the induction of autoimmune diseases is controversial. Studies by Miyoshi et al. [103], and MyllykangasLuosujarvi et al. [104] all suggest that fungal proteins have a role to play in autoimmune diseases. However, further studies are needed to establish the role of fungi in the immunopathology of autoimmune diseases.

\section{Fungal Allergens}

The most common fungi species implicated in allergic reactions are Alternaria, Cladosporium, Aspergillus and Penicillium $[105,106]$, which can be established by the use of a skin prick testing or allergen-specific IgE antibody detection $[107,108]$. The allergenic proteins of these fungi [109] can induce sensitisation and result in immune-mediated diseases such as asthma $[110,111]$, allergic bronchopulmonary diseases [112-114] and/or HP $[115,116]$.

Although progress is being made in identifying and characterising the fungal allergens involved in eliciting allergic immune responses, fungal allergens are thought to be still neglected and underestimated, compared to other aeroallergens $[117,118]$ such as pollen or house dust mites.

Fungi polysensitisation (sensitisation to multiple fungi) or cross-reactivity is frequently observed in clinical cases. This makes the precise identification of a given fungal allergen challenging. This is further complicated by the fact that fungi share several potentially allergenic epitopes, making a precise diagnosis of a specific fungal allergy difficult [119]. The use of component-resolved diagnostic techniques [120] that involve mapping the allergen sensitisation of a patient at a molecular level using purified natural or recombinant allergenic molecules instead of allergenic extracts [121] has enabled progress in attributing fungal allergen sources to allergic manifestations.

Progress has also been made in the characterisation and identification of clinically relevant allergens. Nonetheless, to improve molecular diagnosis both the crossreactive and the species-specific allergens need to be identified [118]. From the relevant literature, some of the fol- 
Table 2. Cross-reactive allergens

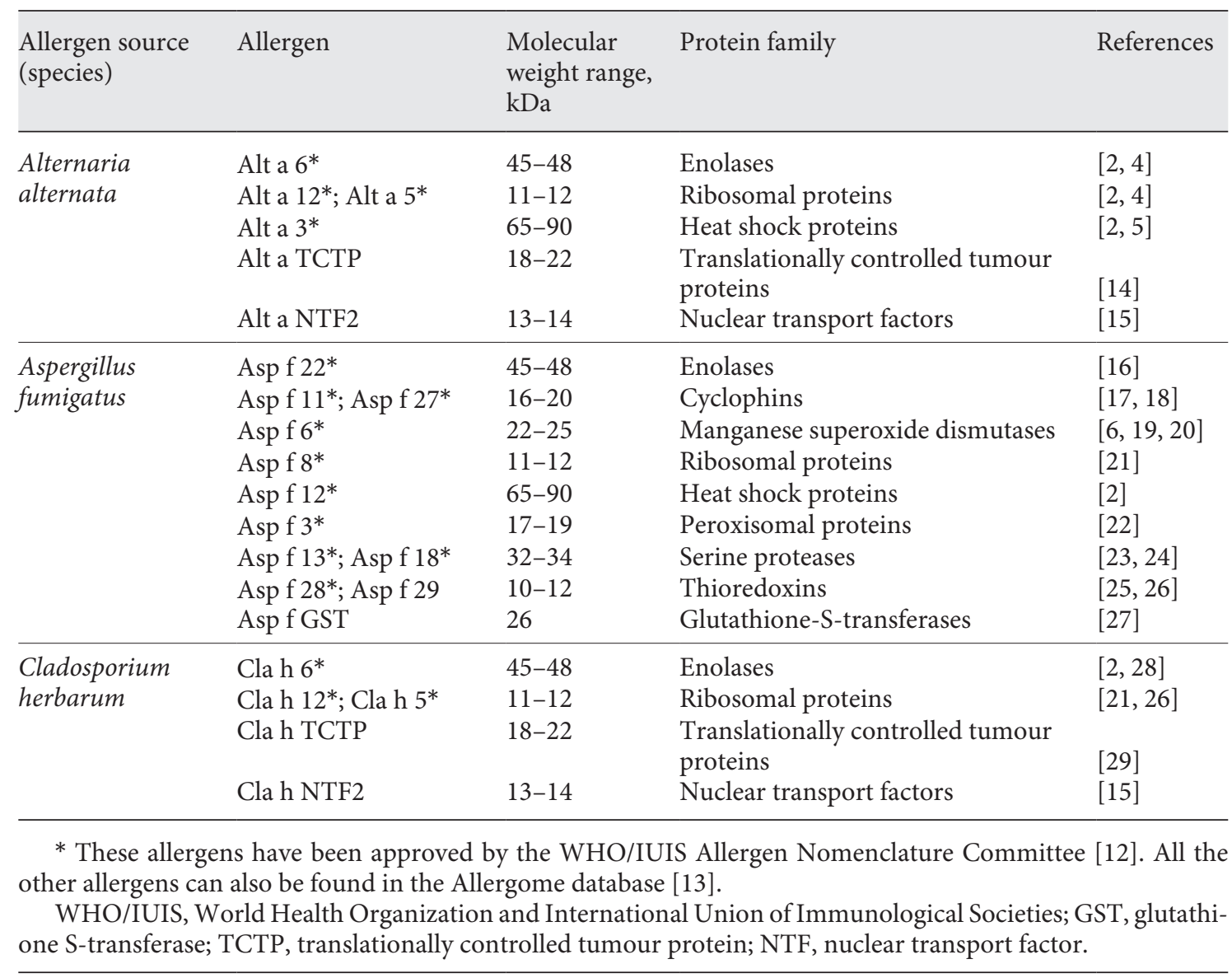

lowing allergens have been identified from Alternaria alternata, Aspergillus fumigatus and Cladosporium herbarum. These are presented in Tables 1 and 2 .

\section{Exposure to Fungi and Fungal Species in Africa}

The mid and hot tropical climates [122] in Africa provide favourable growth conditions for fungi species and as such it is possibly the most exposed of all continents [123]. In addition to the climatic conditions, factors such as poverty make it highly plausible for people in Africa to consume mycotoxin-contaminated food. These mycotoxins are produced by some fungal species as secondary metabolites [124]. Majority of the food crops [125] contaminated are part of the main ingredients in weaning porridge [126], and due to this, it has been suggested that exposure to the mycotoxins maybe a causative factor for child stunting and underweight $[127,128]$ observed in some African children.

Pathogenesis of Immune-Mediated Fungal Diseases in Africa

\section{Pathogenesis in Fungal Allergic Diseases}

In this review, we are looking at the pathogenesis of fungal allergic diseases in a wider study to understand allergic reactivity in Africa. The allergic diseases can result from immune-mediated inflammatory responses to fungal allergen sources causing tissue damage [129]. The fungal allergens can elicit hypersensitivity reactions including of type I (IgE mediated), type III (IgG/IgM-mediated) and type IV (delayed type hypersensitivity), and these may act together to mediate the pathogenesis of different allergic diseases. A schematic illustration of these reactions is shown in Figure 1, but the specific allergens responsible for symptoms remain poorly characterised $[95,117,130]$. Additionally, it is not known why fungal allergens produce more severe airway diseases than other common aeroallergens [67]. One possible explanation could be that colonisation with fungi as well as their ability to actively germinate in the host predisposes the host to immunerelated diseases and severe disease course $[82,131]$. 


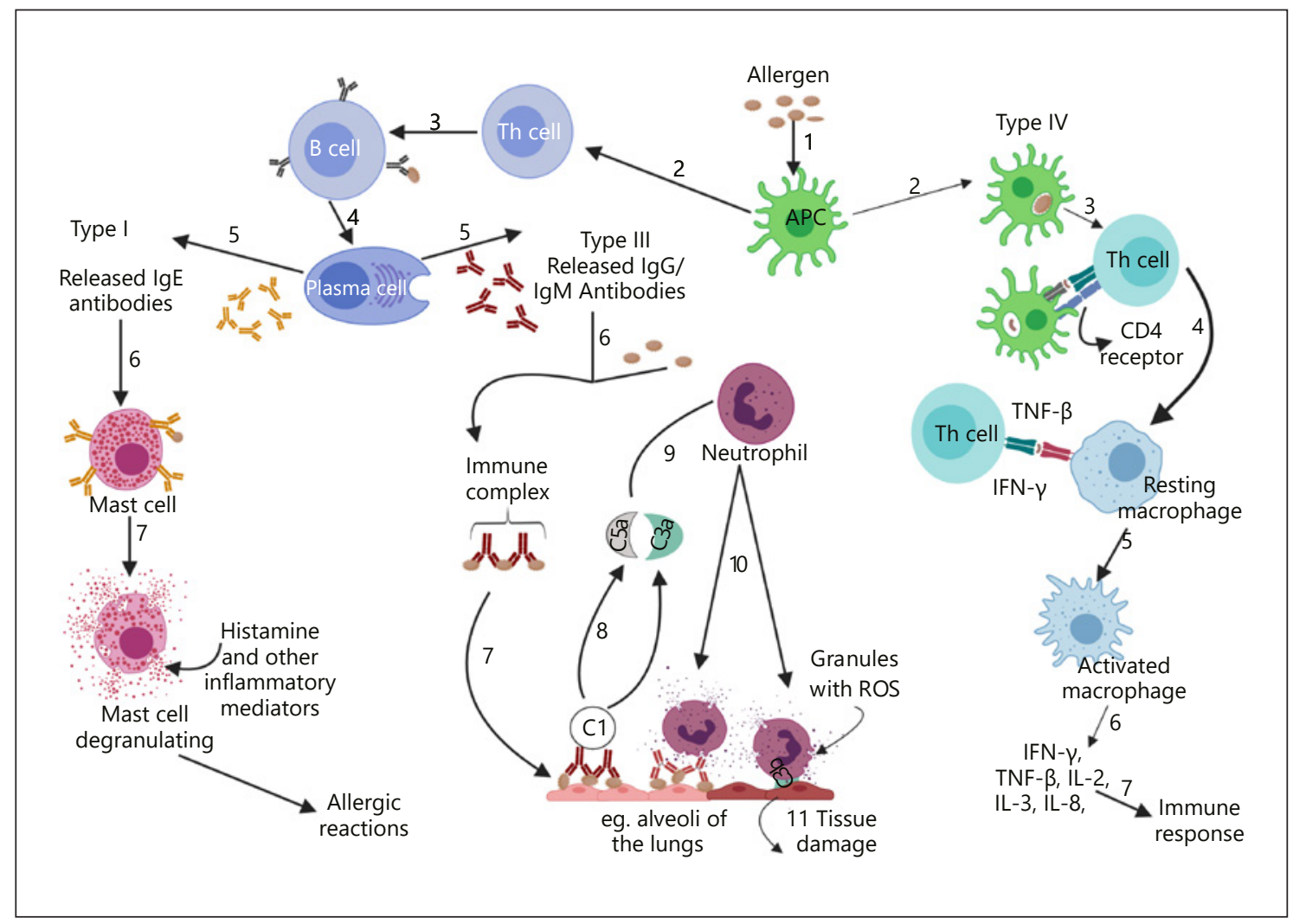

Fig. 1. Mechanisms of hypersensitivity reactions involved in fungal allergy. In the Type I hypersensitivity reaction, the mechanism of action involves preferential production of $\operatorname{IgE}(5)$, in response to allergens and the primary cellular component in this hypersensitivity is the mast cell (6). In Type III hypersensitivity reactions, primary components are soluble immune complexes and complement (C3a and 5a) and the injury is caused by neutrophils. In Type IV hypersensitivity reactions, injury is caused by activated macrophages. Diagram adapted from Rajan [185]. IFN- $\gamma$, interferon gamma.

Allergic sensitisation involves the development of allergen-specific Th2 responses and IgE production. IgE binds to the high-affinity IgE receptor (FceRI) present on mast cells. Re-exposure to the specific allergen results in cross-linking of IgE on the mast cell surface, activation and rapid degranulation of the mast cells, with the secretion of active mediators such as histamine. The late phase response involves an influx of Th2 lymphocytes and eosinophils leading to a more prolonged response with tissue damage $[132,133]$.

Significant progress is currently being made into understanding the mechanistic pathways by which fungi cause or exacerbate allergic diseases such as asthma. It has been reported that fungal cell wall components such as $\beta$-glucans, chitin and proteases are the main source of pathogen-associated molecular patterns recognised by pattern recognition receptors as well as protease activated receptors on the host cells [134]. These cell wall compo- nents have been suggested to be widely conserved across the fungal kingdom and absent in humans, hence ideal targets for immune recognition [135]. When exposed to $\beta$-glucans, chitin and proteases, the epithelial cells mount an immune against these components by releasing chemokines, cytokines and antimicrobial peptides [136]. Repeated exposures to fungi allergens lead to the induction of Th1, Th2 and Th17 reactions and chronic airway inflammation [137-139] as shown in Figure 2.

Fungal proteases induce inflammatory responses by compromising mucociliary clearance, altering the permeability of epithelial barrier, and activating innate immune responses leading to asthma development [140, $141]$. The $\beta$-glucans induce IL-6, IL- 8 and CCL- 20 from airway epithelial cells through Dectin-1 receptor [142, 143]. Chitin induces inflammatory responses characterized by IL-17, IL-23 and TNFa [144] as well induce the expression of IL-25, IL-33 and thymic stromal lympho- 


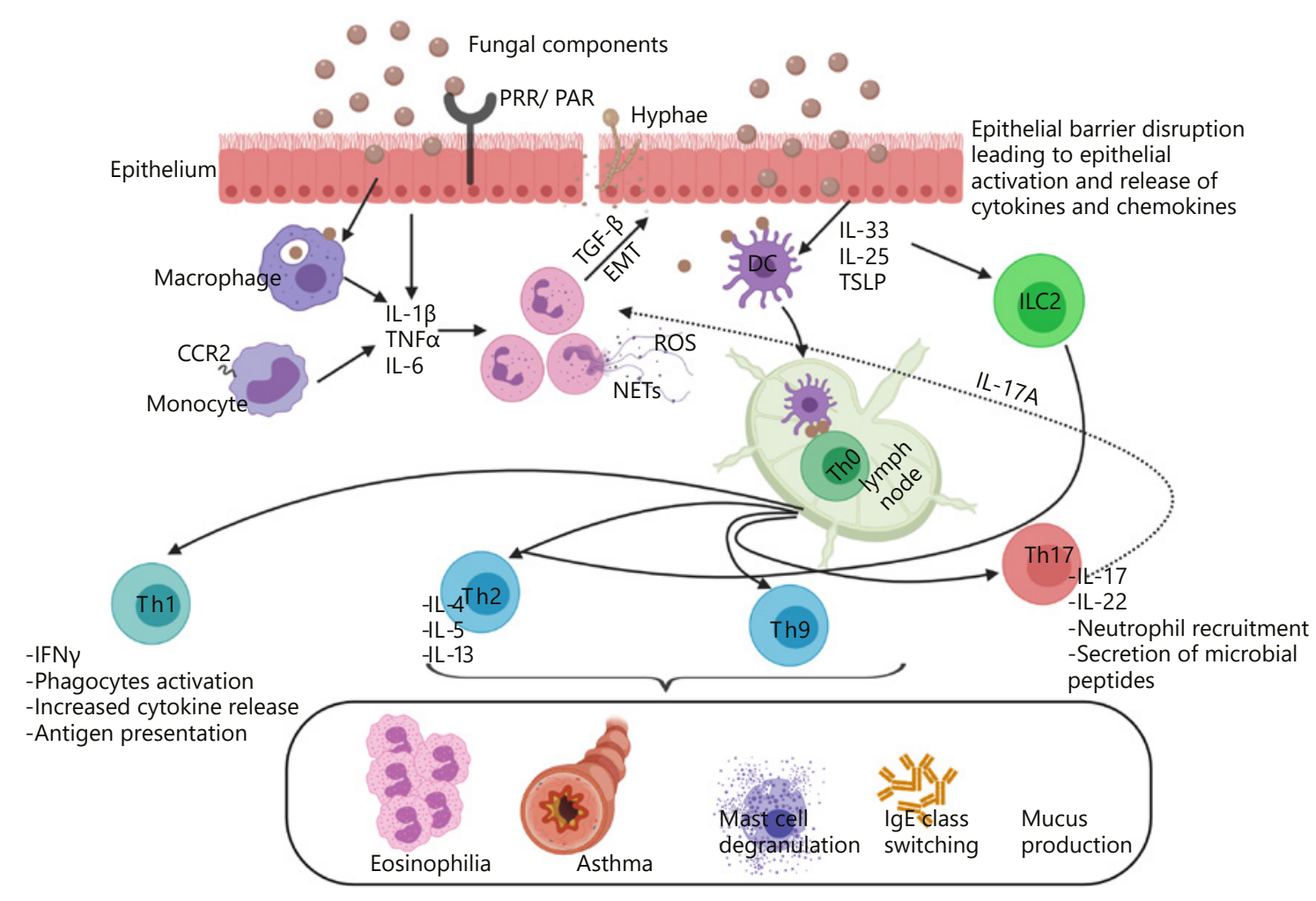

Fig. 2. Cells and cell mediators involved in fungal allergic inflammation. Possible effects of fungal components on the permeability of the airway epithelial and inflammatory responses. The epithelium is exposed to proteolytic enzymes from fungi, which digest proteins of the epithelial layer, making it more permeable. Exposure to fungal components induces the selective release and production of IL-33, IL-25 and thymic stromal lymphopoietin by the airway epithelial cells. Thymic stromal lymphopoietin, IL-33 and
IL-25 activate ILC2s to produce type 2 cytokines such as IL-5 and IL-13, initiating allergic inflammation. Adapted from references $[146,148,182,186-191]$. PRR, pattern recognition receptor; PAR, protease activated receptor; TGF- $\beta$, transforming growth factor beta; EMT, epithelial mesenchymal transition; IFN- $\gamma$, interferon gamma; ILC2, innate lymphoid cells; TSLP, thymic stromal lymphopoietin; CCR, CC chemokine receptor; NETs, neutrophil extracellular traps; ROS, reactive oxygen species. poietin, which activate innate lymphoid cells (ILC2s) [145] to express IL-5 and IL-13, leading to eosinophilia [146] and accumulation of alternatively activated macrophages.

ILC2s have been shown to contribute to the initiation and persistence of fungus-mediated allergic immune responses in mice $[147,148]$, suggesting that they have a role to play in fungal allergy. However, the mechanism that explains how airway exposure to fungal allergens results in increased production and secretion of pro-type 2 cytokines, such as IL-33, leads to activation of ILC2s and other inflammatory cells in airway mucosa, are only partly understood [147]. Therefore, further studies are required to have a better understanding of the mechanistic pathways involved in the pathogenesis of fungal allergy.

\section{Gut Microbiome and Fungal Allergy}

There is increasing evidence that resident microbial communities in the gastrointestinal tract, airways and on the skin contribute to health and disease [149]. Several studies have highlighted that gut microbiome dysbiosis can influence susceptibility to non-infectious diseases [150] such as atopic dermatitis, allergy, cancer, obesity and diabetes [151, 152].

In context of the entire microbiota, fungi are considered a minor component [153] and hence rarely focused on when discussing microbiome which mainly refers to bacteria. The role of gut mycobiome in immune regulation and asthma development has been documented in murine experimental model studies. In particular, Wheel- 
er et al. [154], investigated the importance of a "healthy mycobiota" in the gut in modulating immune function using mice. In this study they found that prolonged oral treatment of mice with anti-fungal drugs increased the abundance of Aspergillus, Epicoccum and Wallemia spp in the gut and exacerbated the development of allergic airway diseases [154]. The authors also reported that inducing alterations in the existing mycobiome could change the course of house dust mite-induced allergic diseases.

In addition, studies by Noverr et al. $[155,156]$ demonstrated that mice develop allergic airway responses if their endogenous microbiota is altered as compared to those with normal microbiota. All these studies suggest that there is a connection between the gut microbiome and allergy at least in animal models. The challenge remains how to interpret these sorts of results from experimental studies in terms of human patients.

It has been observed both in human and experimental models that allergic diseases correlate with widespread use of antibiotics [155-159] and alteration in faecal microbiome, which lead to overgrowth of yeast such as Candida albicans, which can secrete potent prostaglandinlike immune response modulators, involved in inflammation. Given the widespread use of antibiotics in African countries $[160,161]$ and the increasing prevalence of allergic diseases in this continent, there is a likelihood that gut mycobiome are involved in allergic diseases, though studies are needed to investigate this association.

The mycobiome has also been implicated in other diseases such as inflammatory bowel disease [162-164], Crohn's disease [165], Autism [166] as well as Rett syndrome [167]. Benito-Leon et al. [168] hypothesised that the gut mycobiome has a role to play in multiple sclerosis and this was observed in a case-control study [169]. However, further studies are necessary to comprehensively understand the role of the mycobiome in the pathophysiology of these diseases.

\section{Limitations of Mouse Models}

Studies of fungal exposure and allergy have benefited greatly from the use of murine models to evaluate fungal pathology [147, 170-173]. However, little is known about how these specific cell types translate to human patients who have asthma and other allergic diseases [147].

Murine research has contributed to defining the immunological mechanisms underlying allergic asthma and has provided some understanding of the disease [174]. Although mouse models are widely used, it is important to be cognizant of the fact that mouse airways differ sig- nificantly from human airways, in terms of the anatomy, development and physiology as well as in the nature of allergen exposure $[174,175]$. These differences underly some of the challenges in translating findings from experimental models to human disease [176].

Mice do not have asthma and do not exhibit spontaneous "symptoms" consistent with asthma [177], and hence, are usually manipulated to develop allergic/Th2-type immune responses. This results in sensitisation of the animal by systemic administration of the allergen, whereas in humans there is no systemic administration of allergen. The allergic diseases in mice are acute and transient, so it is difficult to establish chronic allergic diseases in mice [178]. Furthermore, experimental mice are inbred strains whereas humans are not; hence, other environmental factors might also influence how humans respond to the allergens [175]. Overall, this leads to difficulties in transposing mice immunological responses into useful human data [179].

\section{Knowledge Gaps Relevant to Improve Fungal Allergy and Human Health}

Although fungal-related diseases are now recognised as a growing problem globally [6], there continues to be a paucity of epidemiological data in Africa as majority of the published data is from Europe and the States [16]. Additionally, in Africa, there are diagnostic challenges as most people have limited healthcare access due to cost barriers, poor healthcare infrastructures as well as lack of expertise [180].

In general, there is paucity of studies in relevant model systems for human fungal disease; hence, mechanism of pathogenesis remains unclear despite all the research progress made in experimental models. It has been suggested that human microbiome (ensemble of microbes that reside in and on and interact with the human body) [181] has a crucial role in the development and severity of allergic disorders and are involved in their resolution or chronicity. Currently, there is still a limited understanding of the interactions between the human microbiome, immune system and allergic disorders [182].

Allergic sensitisation and inflammation studies of human populations and experimental studies in animal models point to interactions between the external environment, the microbiome, and immune function in early life as causing an underlying predisposition to allergic sensitisation [98]. The majority of the studies report that an alteration in the microbiome [183] is associated with 
development or exacerbation of allergic conditions such as asthma [154-156, 184]. Only a limited number of studies have been carried out in human populations, highlighting the need to further extend present knowledge regarding the relationship between the human microbiome and fungal allergy, which would give insight on the pathogenesis of fungal-induced allergies.

Thus, we will be investigating the role of human microbiome in fungal allergy. Of particular interest, is the association of gut mycobiome in the development of sensitivity or tolerance to fungal allergens.

\section{Conclusion}

Although progress has been made on identification and characterisation of fungal allergens, the pathogenesis of fungal allergic diseases still remains elusive because of the complexity of the immunological response to fungi exposure, especially in African populations. Understanding this will impact on the way allergic diseases are diagnosed and managed in these populations.

Furthermore, there is a need to further investigate the association between the gut mycobiome and fungal allergies as well as mechanistic pathways of interaction if any, between the two. This will inform the development of appropriate diagnostics and interventions for fungal allergic diseases, particularly those occurring as co- or multimorbidities. This is critical for African health systems where the growing burden of non-infectious diseases must be managed on a background of endemic and epidemic infectious diseases.

\section{Acknowledgements}

We thank all the members of the Parasite Immuno-epidemiology Group at the University of Edinburgh for their valuable comments in shaping the manuscript.

\section{Disclosure Statement}

The authors declare that there is no conflict of interest.

\section{Funding Sources}

This research was commissioned by the National Institute of Health Research (NIHR) Global Health Research programme $(16 / 136 / 33)$ using UK aid from the UK Government. The views expressed in this publication are those of the authors and not necessarily those of the NIHR or the department of Health and Social care. All authors are supported by OAK Foundation.

\section{Author Contributions}

All authors contributed to the draft manuscript editing, reviewing and approval of the final version of the manuscript.

\section{References}

1 Dighton J. Fungi in ecosystem processes. CRC Press; 2016. https://doi.org/10.1201/b19652.

2 Powers-Fletcher MV, Kendall BA, Griffin AT, Hanson KE. Filamentous fungi. Diagnostic Microbiology of the Immunocompromised Host; 2016. pp. 311-41.

3 Burge HA. Fungus allergens. Clin Rev Allergy. 1985 Jul;3(3):319-29.

4 Rajasingham R, Smith RM, Park BJ, Jarvis JN, Govender NP, Chiller TM, et al. Global burden of disease of HIV-associated cryptococcal meningitis: an updated analysis. Lancet Infect Dis. 2017 Aug; 17(8):873-81.

5 Bienvenu AL, Traore K, Plekhanova I, Bouchrik M, Bossard C, Picot S. Pneumocystis pneumonia suspected cases in 604 non-HIV and HIV patients. Int J Infect Dis. 2016 May; 46:11-7.

6 Centers for Disease Control and Prevention: Fungal diseases, 2019.

7 Brown GD, Denning DW, Gow NA, Levitz SM, Netea MG, White TC. Hidden killers: human fungal infections. Sci Transl Med. 2012 Dec;4(165):165rv13.
8 Denning DW, Pleuvry A, Cole DC. Global burden of chronic pulmonary aspergillosis as a sequel to pulmonary tuberculosis. Bull World Health Organ. 2011 Dec;89(12):864-72.

9 Medrek SK, Kao CC, Yang DH, Hanania NA, Parulekar AD. Fungal Sensitization Is Associated with Increased Risk of Life-Threatening Asthma. J Allergy Clin Immunol Pract. 2017 Jul - Aug;5(4):1025-31.e2.

10 Silva-Rocha WP, de Azevedo MF, Chaves GM. Epidemiology and fungal species distribution of superficial mycoses in Northeast Brazil. J Mycol Med. 2017 Mar;27(1):57-64.

11 Kim SH, Cho SH, Youn SK, Park JS, Choi JT, Bak YS, et al. Epidemiological Characterization of Skin Fungal Infections Between the Years 2006 and 2010 in Korea. Osong Public Health Res Perspect. 2015 Dec;6(6):341-5.

12 Hay RJ. 82 - Superficial Mycoses. In: Ryan ET, Hill DR, Solomon T, Aronson NE, Endy TP, editors. Hunter's Tropical Medicine and Emerging Infectious Diseases. 10th ed. London: Content Repository Only; 2020. pp. 64852.
13 Horner WE, Helbling A, Salvaggio JE, Lehrer SB. Fungal allergens. Clin Microbiol Rev. 1995 Apr;8(2):161-79.

14 Queiroz-Telles F, Fahal AH, Falci DR, Caceres DH, Chiller T, Pasqualotto AC. Neglected endemic mycoses. Lancet Infect Dis. 2017 Nov; 17(11):e367-77.

15 Özenci V, Klingspor L, Ullberg M, Chryssanthou E, Denning DW, Kondori N. Estimated burden of fungal infections in Sweden. Mycoses. 2019 Nov;62(11):1043-48.

16 Bongomin F, Gago S, Oladele RO, Denning DW. Global and multi-national prevalence of fungal diseases-estimate precision. J Fungi (Basel). 2017 Oct;3(4):57.

17 Infections GAFFF: Burden of Serious fungal diseases in Ghana, South Africa, Ethopia and Taiwan presented in Dubai at GCCMID; 2018.

18 Ocansey BK, Pesewu GA, Codjoe FS, OseiDjarbeng S, Feglo PK, Denning DW. Estimated Burden of Serious Fungal Infections in Ghana. J Fungi (Basel). 2019 May;5(2):38.
Pathogenesis of Immune-Mediated Fungal Diseases in Africa
Int Arch Allergy Immunol 2020;181:257-269 DOI: 10.1159/000506009 
19 Schwartz IS, Boyles TH, Kenyon CR, Hoving JC, Brown GD, Denning DW. The estimated burden of fungal disease in South Africa. S Afr Med J. 2019;109(11):885-92.

20 Li J, Vinh DC, Casanova JL, Puel A. Inborn errors of immunity underlying fungal diseases in otherwise healthy individuals. Curr Opin Microbiol. 2017 Dec;40:46-57.

21 Lilic D. Unravelling fungal immunity through primary immune deficiencies. Curr Opin $\mathrm{Mi}$ crobiol. 2012 Aug;15(4):420-6.

22 Garcia-Solache MA, Casadevall A. Global warming will bring new fungal diseases for mammals. MBio. 2010 May;1(1):e0006100010 .

23 Vallabhaneni S, Mody RK, Walker T, Chiller T. The global burden of fungal diseases. Infect Dis Clin North Am. 2016 Mar;30(1):1-11

24 Knutsen AP, Bush RK, Demain JG, Denning DW, Dixit A, Fairs A, et al. Fungi and allergic lower respiratory tract diseases. J Allergy Clin Immunol. 2012 Feb;129(2):280-91.

25 Fisher MC, Henk DA, Briggs CJ, Brownstein JS, Madoff LC, McCraw SL, et al. Emerging fungal threats to animal, plant and ecosystem health. Nature. 2012 Apr;484(7393):186-94.

26 Casadevall A. Fungal diseases in the 21st Century: the near and far horizons. Pathog Immun. 2018;3(2):183-96.

27 Casadevall A. Don't forget the fungi when considering global catastrophic biorisks. Health Secur. 2017 Jul/Aug;15(4):341-2.

28 Almeida F, Rodrigues ML, Coelho C. The still underestimated problem of fungal diseases worldwide. Front Microbiol. 2019 Feb;10:214.

29 Havlickova B, Czaika VA, Friedrich M. Epidemiological trends in skin mycoses worldwide. Mycoses. 2008 Sep;51 Suppl 4:2-15.

30 Hay SI, Abajobir AA, Abate KH, Abbafati C, Abbas KM, Abd-Allah F, et al.; GBD 2016 DALYs and HALE Collaborators. Global, regional, and national disability-adjusted lifeyears (DALYs) for 333 diseases and injuries and healthy life expectancy (HALE) for 195 countries and territories, 1990-2016: a systematic analysis for the Global Burden of Disease Study 2016. Lancet. 2017 Sep;390(10100): 1260-344.

31 World Health Organization: Malaria, 2019.

32 World Health Organization. Tuberculosis (Edinb). 2018.

33 World Health Organization. HIV AIDS (Auckl). 2019.

34 Global Action Fund For Fungal Infections (GAFFI), 2015

35 Oladele RO, Denning DW. Burden of serious fungal infection in Nigeria. West Afr J Med. 2014 Apr-Jun;33(2):107-14.

36 Kalua K, Zimba B, Denning DW. Estimated burden of serious fungal infections in Malawi. J Fungi (Basel). 2018 May;4(2):61.

37 Badiane AS, Ndiaye D, Denning DW. Burden of fungal infections in Senegal. Mycoses. 2015 Oct;58 Suppl 5:63-9.

38 Mandengue CE, Denning DW. The burden of serious fungal infections in Cameroon. J Fungi (Basel). 2018 Mar;4(2):44.
39 Sacarlal J, Denning DW. Estimated burden of serious fungal infections in Mozambique. J Fungi (Basel). 2018 Jun;4(3):75.

40 Chekiri-Talbi M, Denning DW. Burden of fungal infections in Algeria. Eur J Clin Microbiol Infect Dis. 2017 Jun;36(6):999-1004.

41 Faini D, Maokola W, Furrer H, Hatz C, Battegay M, Tanner M, et al. Burden of serious fungal infections in Tanzania. Mycoses. 2015 Oct;58 Suppl 5:70-9.

42 Dunaiski CM, Denning DW. Estimated Burden of Fungal Infections in Namibia. J Fungi (Basel). 2019 Aug;5(3):75.

43 Reijula K, Leino M, Mussalo-Rauhamaa H, Nikulin M, Alenius H, Mikkola J, et al. IgEmediated allergy to fungal allergens in Finland with special reference to Alternaria alternata and Cladosporium herbarum. Ann Allergy Asthma Immunol. 2003 Sep;91(3): 280-7.

44 Yazdanbakhsh M, Kremsner PG, van Ree R. Allergy, parasites, and the hygiene hypothesis. Science. 2002 Apr;296(5567):490-4.

45 Okada H, Kuhn C, Feillet H, Bach JF. The 'hygiene hypothesis' for autoimmune and allergic diseases: an update. Clin Exp Immunol. 2010 Apr;160(1):1-9.

46 Zar HJ, Ehrlich RI, Workman L, Weinberg EG. The changing prevalence of asthma, allergic rhinitis and atopic eczema in African adolescents from 1995 to 2002. Pediatr Allergy Immunol. 2007 Nov;18(7):560-5.

47 Beasley R; The International Study of Asthma and Allergies in Childhood (ISAAC) Steering Committee. Worldwide variation in prevalence of symptoms of asthma, allergic rhinoconjunctivitis, and atopic eczema: ISAAC. Lancet. 1998 Apr;351(9111):1225-32.

48 Pearce N, Aït-Khaled N, Beasley R, Mallol J, Keil U, Mitchell E, et al.; ISAAC Phase Three Study Group. Worldwide trends in the prevalence of asthma symptoms: phase III of the International Study of Asthma and Allergies in Childhood (ISAAC). Thorax. 2007 Sep; 62(9):758-66

49 Mallol J, Crane J, von Mutius E, Odhiambo J, Keil U, Stewart A; ISAAC Phase Three Study Group. The International Study of Asthma and Allergies in Childhood (ISAAC) Phase Three: a global synthesis. Allergol Immunopathol (Madr). 2013 Mar-Apr;41(2):73-85.

50 Sibanda EN. Inhalant allergies in Zimbabwe: a common problem. Int Arch Allergy Immunol. 2003 Jan;130(1):2-9.

51 Nriagu J, Robins T, Gary L, Liggans G, Davila $R$, Supuwood K, et al. Prevalence of asthma and respiratory symptoms in south-central Durban, South Africa. Eur J Epidemiol. 1999 Sep;15(8):747-55.

52 Ndiaye M, Bousquet J. Allergies and parasitoses in sub-Saharan Africa. Clin Rev Allergy Immunol. 2004 Apr;26(2):105-13.

53 Obeng BB, Hartgers F, Boakye D, Yazdanbakhsh M. Out of Africa: what can be learned from the studies of allergic disorders in Africa and Africans? Curr Opin Allergy Clin Immunol. 2008 Oct;8(5):391-7.
54 Mbugi EV, Chilongola JO. Allergic disorders in Africa and africans: is it primarily a priority? World Allergy Organ J. 2010 May;3(5): $175-81$.

55 Kwizera R, Musaazi J, Meya DB, Worodria W, Bwanga F, Kajumbula H, et al. Burden of fungal asthma in Africa: A systematic review and meta-analysis. PLoS One. 2019 May; 14(5):e0216568.

56 Green R, Luyt D. Clinical characteristics of childhood asthmatics in Johannesburg. S Afr Med J. 1997 Jul;87(7):878-82.

57 Kung SJ, Steenhoff AP. Allergy in Botswana. Curr Allergy Clin Immunol. 2013;26:202-9.

58 Robert VA, Casadevall A. Vertebrate endothermy restricts most fungi as potential pathogens. J Infect Dis. 2009 Nov;200(10): 1623-6.

59 Chakrabarti A, Chatterjee SS, Das A, Shivaprakash MR. Invasive aspergillosis in developing countries. Med Mycol. 2011 Apr; 49(Suppl 1):S35-47.

60 Chakrabarti A, Singh R. The emerging epidemiology of mould infections in developing countries. Curr Opin Infect Dis. 2011 Dec: 24(6):521-6.

61 Simon-Nobbe B, Denk U, Pöll V, Rid R, Breitenbach $M$. The spectrum of fungal allergy. Int Arch Allergy Immunol. 2008;145(1):5886.

62 Hurraß J, Heinzow B, Aurbach U, Bergmann KC, Bufe A, Buzina W, et al. Medical diagnostics for indoor mold exposure. Int J Hyg Environ Health. 2017 Apr;220(2 Pt B):305-28.

63 Jaakkola MS, Quansah R, Hugg TT, Heikkinen SA, Jaakkola JJ. Association of indoor dampness and molds with rhinitis risk: a systematic review and meta-analysis. J Allergy Clin Immunol. 2013 Nov;132(5):1099-110. e18.

64 Mohammadi A, Hashemi SM, Abtahi SH, Lajevardi SM, Kianipour S, Mohammadi R. An investigation on non-invasive fungal sinusitis; Molecular identification of etiologic agents. J Res Med Sci. 2017 May;22(1):67-67.

65 Glatz M, Bosshard PP, Hoetzenecker W, Schmid-Grendelmeier P. The Role of Malassezia spp. in Atopic Dermatitis. J Clin Med. 2015 May;4(6):1217-28.

66 Black PN, Udy AA, Brodie SM. Sensitivity to fungal allergens is a risk factor for life-threatening asthma. Allergy. 2000 May;55(5):501-4.

67 Chowdhary A, Agarwal K, Kathuria S, Gaur SN, Randhawa HS, Meis JF. Allergic bronchopulmonary mycosis due to fungi other than Aspergillus: a global overview. Crit Rev Microbiol. 2014 Feb;40(1):30-48.

68 Vasakova M, Morell F, Walsh S, Leslie K, Raghu G. Hypersensitivity Pneumonitis: Perspectives in Diagnosis and Management. Am J Respir Crit Care Med. 2017 Sep;196(6):680-9.

69 Katotomichelakis M, Danielides G, Iliou T, Anastassopoulos G, Nikolaidis C, Kirodymos $\mathrm{E}$, et al. Allergic sensitization prevalence in a children and adolescent population of northeastern Greece region. Int J Pediatr Otorhinolaryngol. 2016 Oct;89:33-7. 
70 Wheatley LM, Togias A. Clinical practice. Allergic rhinitis. N Engl J Med. 2015 Jan;372(5): 456-63.

71 Salo PM, Arbes SJ Jr, Jaramillo R, Calatroni A, Weir $\mathrm{CH}$, Sever ML, et al. Prevalence of allergic sensitization in the United States: results from the National Health and Nutrition Examination Survey (NHANES) 2005-2006. J Allergy Clin Immunol. 2014 Aug;134(2):3509.

72 Cibella F, Ferrante G, Cuttitta G, Bucchieri S, Melis MR, La Grutta S, et al. The burden of rhinitis and rhinoconjunctivitis in adolescents. Allergy Asthma Immunol Res. 2015 Jan;7(1):44-50.

73 Shaaban R, Zureik M, Soussan D, Neukirch C, Heinrich J, Sunyer J, et al. Rhinitis and onset of asthma: a longitudinal population-based study. Lancet. 2008 Sep;372(9643):1049-57.

74 Guerra S, Sherrill DL, Martinez FD, Barbee RA. Rhinitis as an independent risk factor for adult-onset asthma. J Allergy Clin Immunol. 2002 Mar;109(3):419-25.

75 Alfonso SA, Fawley JD, Alexa Lu X. Conjunctivitis. Prim Care. 2015 Sep;42(3):325-45.

76 Leonardi A, Piliego F, Castegnaro A, Lazzarini D, La Gloria Valerio A, Mattana $\mathrm{P}$, et al. Allergic conjunctivitis: a cross-sectional study. Clin Exp Allergy. 2015 Jun;45(6):111825.

77 Rathi VM, Murthy SI. Allergic conjunctivitis. Community Eye Health. 2017;30(99):S7-10.

78 Nutten S. Atopic dermatitis: global epidemiology and risk factors. Ann Nutr Metab. 2015; 66 Suppl 1:8-16.

79 Pyun BY. Natural history and risk factors of atopic dermatitis in children. Allergy Asthma Immunol Res. 2015 Mar;7(2):101-5.

80 Čelakovská J, Bukač J, Ettler K, Vaneckova J, Krcmova I, Ettlerova K. Sensitisation to fungi in atopic dermatitis patients over 14 years of age and the relation to the occurrence of food hypersensitivity reactions. Mycoses. 2018 Feb;61(2):88-95.

81 Kurup VP, Shen HD, Vijay H. Immunobiology of fungal allergens. Int Arch Allergy Immunol. 2002 Nov;129(3):181-8.

82 Zukiewicz-Sobczak WA. The role of fungi in allergic diseases. Postepy Dermatol Alergol. 2013 Feb;30(1):42-5.

83 Fukutomi Y, Tanimoto H, Yasueda H, Taniguchi M. Serological diagnosis of allergic bronchopulmonary mycosis: progress and challenges. Allergol Int. 2016 Jan;65(1):30-6.

84 Agarwal R, Aggarwal AN, Dhooria S, Singh Sehgal I, Garg M, Saikia B, et al. A randomised trial of glucocorticoids in acute-stage allergic bronchopulmonary aspergillosis complicating asthma. Eur Respir J. 2016 Feb;47(2):4908.

85 Becker KL, Gresnigt MS, Smeekens SP, Jacobs CW, Magis-Escurra C, Jaeger M, et al. Pattern recognition pathways leading to a Th2 cytokine bias in allergic bronchopulmonary aspergillosis patients. Clin Exp Allergy. 2015 Feb;45(2):423-37.
86 Ishiguro T, Takayanagi N, Kagiyama N, Shimizu Y, Yanagisawa T, Sugita Y. Clinical characteristics of biopsy-proven allergic bronchopulmonary mycosis: variety in causative fungi and laboratory findings. Intern Med. 2014;53(13):1407-11.

87 White LC, Jang DW, Yelvertan JC, Kountakis SE. Bony erosion patterns in patients with allergic fungal sinusitis. Am J Rhinol Allergy. 2015 Jul-Aug;29(4):243-5.

88 Correll DP, Luzi SA, Nelson BL. Allergic Fungal Sinusitis. Head Neck Pathol. 2015 Dec; 9(4):488-91.

89 Selman M, Buendía-Roldán I, Navarro C, Gaxiola M. Hypersensitivity Pneumonitis. In: Baughman RP, Carbone RG, Nathan SD, editors. Pulmonary Hypertension and Interstitial Lung Disease. Cham: Springer International Publishing; 2017. pp. 145-64.

90 Quirce S, Vandenplas O, Campo P, Cruz MJ, de Blay F, Koschel D, et al. Occupational hypersensitivity pneumonitis: an EAACI position paper. Allergy. 2016 Jun;71(6):765-79.

91 Tham R, Vicendese D, Dharmage SC, Hyndman RJ, Newbigin E, Lewis E, et al. Associations between outdoor fungal spores and childhood and adolescent asthma hospitalizations. J Allergy Clin Immunol. 2017 Apr; 139(4):1140-47.e4.

92 O’Driscoll BR, Hopkinson LC, Denning DW. Mold sensitization is common amongst patients with severe asthma requiring multiple hospital admissions. BMC Pulm Med. 2005 Feb;5(1):4.

93 Tanaka A, Fujiwara A, Uchida Y, Yamaguchi M, Ohta S, Homma T, et al. Evaluation of the association between sensitization to common inhalant fungi and poor asthma control. Ann Allergy Asthma Immunol. 2016 Aug;117(2): 163-8.e1.

94 Frew AJ. Mold allergy: some progress made, more needed. J Allergy Clin Immunol. 2004 Feb;113(2):216-8.

95 Agarwal R, Gupta D. Severe asthma and fungi: current evidence. Med Mycol. 2011 Apr; 49(Suppl 1):S150-7.

96 Borchers AT, Chang C, Eric Gershwin M. Mold and Human Health: a Reality Check. Clin Rev Allergy Immunol. 2017 Jun;52(3): $305-22$.

97 Sears MR, Greene JM, Willan AR, Wiecek EM, Taylor DR, Flannery EM, et al. A longitudinal, population-based, cohort study of childhood asthma followed to adulthood. N Engl J Med. 2003 Oct;349(15):1414-22.

98 Lynch SV, Boushey HA. The microbiome and development of allergic disease. Curr Opin Allergy Clin Immunol. 2016 Apr;16(2):16571.

99 Wertz DA, Pollack M, Rodgers K, Bohn RL, Sacco P, Sullivan SD. Impact of asthma control on sleep, attendance at work, normal activities, and disease burden. Ann Allergy Asthma Immunol. 2010 Aug;105(2):118-23.
100 Schmid-Grendelmeier P, Flückiger S, Disch $\mathrm{R}$, Trautmann A, Wüthrich B, Blaser K, et al. IgE-mediated and $\mathrm{T}$ cell-mediated autoimmunity against manganese superoxide dismutase in atopic dermatitis. J Allergy Clin Immunol. 2005 May;115(5):1068-75.

101 Wucherpfennig KW. Mechanisms for the induction of autoimmunity by infectious agents. J Clin Invest. 2001 Oct;108(8):1097104.

102 Hradetzky S, Werfel T, Rösner LM. Autoallergy in atopic dermatitis. Allergo J Int. 2015 24(1):16-22.

103 Miyoshi J, Sofia MA, Pierre JF. The evidence for fungus in Crohn's disease pathogenesis. Clin J Gastroenterol. 2018 Dec;11(6):449-56.

104 Myllykangas-Luosujärvi R, Seuri M, Husman T, Korhonen R, Pakkala K, Aho K. A cluster of inflammatory rheumatic diseases in a moisture-damaged office. Clin Exp Rheumatol. 2002 Nov-Dec;20(6):833-6.

105 Bogacka E, Jahnz-Rózyk K. [Allergy to fungal antigens]. Pol Merkuriusz Lek. 2003;14 381-4.

106 Ziaee A, Zia M, Goli M. Identification of saprophytic and allergenic fungi in indoor and outdoor environments. Environ Monit Assess. 2018 Sep;190(10):574.

107 Baxi SN, Portnoy JM, Larenas-Linnemann D, Phipatanakul W, Barnes C, Baxi S, et al. Environmental Allergens Workgroup. Exposure and Health Effects of Fungi on $\mathrm{Hu}$ mans. J Allergy Clin Immunol Pract. 2016 May-Jun;4(3):396-404.

108 Larenas-Linnemann D, Baxi S, Phipatanakul W, Portnoy JM; Environmental Allergens Workgroup. Clinical evaluation and management of patients with suspected fungus sensitivity. J Allergy Clin Immunol Pract. 2016 May-Jun;4(3):405-14.

109 Wüthrich B. Epidemiology of the allergic diseases: are they really on the increase? Int Arch Allergy Appl Immunol. 1989;90 Suppl 1:3-10.

110 Downs SH, Mitakakis TZ, Marks GB, Car NG, Belousova EG, Leüppi JD, et al. Clinical importance of Alternaria exposure in children. Am J Respir Crit Care Med. 2001 Aug; 164(3):455-9.

111 Latgé JP. The pathobiology of Aspergillus fumigatus. Trends Microbiol. 2001 Aug; 9(8):382-9.

112 Moreno-Ancillo A, Díaz-Pena JM, Ferrer A, Martín-Muñoz F, Martín-Barroso JA, Martin-Esteban M, et al. Allergic bronchopulmonary cladosporiosis in a child. J Allergy Clin Immunol. 1996 Feb;97(2):714-5.

113 Deepak D, Singh Rajput M, Sharma B, Chowdhary A. Allergic Bronchopulmonary Mycosis due to fungi other than Aspergillus. Eur Ann Allergy Clin Immunol. 2019 Mar; 51(2):75-9.

114 Kalaiyarasan, Jain AK, Puri M, Tayal D, Singhal R, Sarin R. Prevalence of allergic bronchopulmonary aspergillosis in asthmatic patients: A prospective institutional study. Indian J Tuberc. 2018 Oct;65(4):285-9.
Pathogenesis of Immune-Mediated Fungal Diseases in Africa
Int Arch Allergy Immunol 2020;181:257-269 DOI: $10.1159 / 000506009$ 
115 Ogawa H, Fujimura M, Tofuku Y. Allergic bronchopulmonary fungal disease caused by Saccharomyces cerevisiae. J Asthma. 2004 Apr;41(2):223-8.

116 Chiba S, Okada S, Suzuki Y, Watanuki Z, Mitsuishi Y, Igusa R, et al. Cladosporium species-related hypersensitivity pneumonitis in household environments. Intern Med. 2009;48(5):363-7.

117 Crameri R, Garbani M, Rhyner C, Huitema C. Fungi: the neglected allergenic sources. Allergy. $2014 \mathrm{Feb}$;69(2):176-85.

118 Gabriel MF, Postigo I, Tomaz CT, Martínez J. Alternaria alternata allergens: markers of exposure, phylogeny and risk of fungi-induced respiratory allergy. Environ Int. 2016 Apr-May;89-90:71-80.

119 Crameri R, Zeller S, Glaser AG, Vilhelmsson $\mathrm{M}$, Rhyner C. Cross-reactivity among fungal allergens: a clinically relevant phenomenon? Mycoses. 2009 Mar;52(2):99-106.

120 Treudler R, Simon JC. Overview of component resolved diagnostics. Curr Allergy Asthma Rep. 2013 Feb;13(1):110-7.

121 Vieira T, Lopes C, Pereira AM, Araújo L, Moreira A, Delgado L. Microarray based IgE detection in poly-sensitized allergic patients with suspected food allergy - an approach in four clinical cases. Allergol Immunopathol (Madr). 2012 May-Jun;40(3):172-80.

122 Lehmann S, Sprünken A, Wagner N, Tenbrock $\mathrm{K}$, Ott $\mathrm{H}$. Clinical relevance of IgEmediated sensitization against the mould Alternaria alternata in children with asthma. Ther Adv Respir Dis. 2017 Jan;11(1):30-9.

123 Gbashi S, Madala NE, Adekoya I, Adebo O, De Saeger S, De Boevre M, Njobeh PB. The socio-economic impact of mycotoxin contamination in Africa. 2018.

124 Zain ME. Impact of mycotoxins on humans and animals. J Saudi Chem Soc. 2011;15(2): 129-44.

125 World Health Organization: Aflatoxins. 2018.

126 Obade MI, Andang'o P, Obonyo C, Lusweti F. Exposure of children 4 to 6 months of age to aflatoxin in Kisumu County, Kenya. Afr J Food Agric Nutr Dev. 2015;15:9949-63.

127 Gong YY, Cardwell K, Hounsa A, Egal S, Turner PC, Hall AJ, et al. Dietary aflatoxin exposure and impaired growth in young children from Benin and Togo: cross sectional study. BMJ. 2002 Jul;325(7354):201.

128 Gong Y, Hounsa A, Egal S, Turner PC, Sutcliffe AE, Hall AJ, et al. Postweaning exposure to aflatoxin results in impaired child growth: a longitudinal study in Benin, West Africa. Environ Health Perspect. 2004 Sep; 112(13):1334-8

129 Denning DW, Chakrabarti A. Pulmonary and sinus fungal diseases in non-immunocompromised patients. Lancet Infect Dis. 2017 Nov; 17(11):e357-66.
130 Williams PB, Barnes CS, Portnoy JM, Barnes C, Baxi S, Grimes C, et al.; Environmental Allergens Workgroup. Innate and Adaptive Immune Response to Fungal Products and Allergens. J Allergy Clin Immunol Pract. 2016 May-Jun;4(3):386-95.

131 Denning DW, O’Driscoll BR, Hogaboam CM, Bowyer P, Niven RM. The link between fungi and severe asthma: a summary of the evidence. Eur Respir J. 2006 Mar;27(3):61526.

132 Dimeloe S, Nanzer A, Ryanna K, Hawrylowicz C. Regulatory T cells, inflammation and the allergic response-The role of glucocorticoids and Vitamin D. J Steroid Biochem Mol Biol. 2010 May;120(2-3):86-95.

133 Gauvreau GM, El-Gammal AI, O’Byrne PM. Allergen-induced airway responses. Eur Respir J. 2015 Sep;46(3):819-31.

134 Lambrecht BN, Hammad H. The immunology of asthma. Nat Immunol. 2015 Jan; 16(1):45-56.

135 Zhang Z, Reponen T, Hershey GK. Fungal Exposure and Asthma: IgE and Non-IgEMediated Mechanisms. Curr Allergy Asthma Rep. 2016 Nov; 16(12):86.

136 Rowley JE. The Interaction of Aspergillus Fumigatus With the Respiratory Epithelium. United Kingdom: The University of Manchester; 2014.

137 Bacher P, Kniemeyer O, Schönbrunn A, Sawitzki B, Assenmacher M, Rietschel E, et al. Antigen-specific expansion of human regulatory $\mathrm{T}$ cells as a major tolerance mechanism against mucosal fungi. Mucosal Immunol. 2014 Jul;7(4):916-28.

138 Bacher P, Hohnstein T, Beerbaum E, Rocker M, Blango MG, Kaufmann S, et al. Human Anti-fungal Th17 Immunity and Pathology Rely on Cross-Reactivity against Candida albicans. Cell. 2019 Mar;176(6):1340-55.e15.

139 Dewi IM, van de Veerdonk FL, Gresnigt MS The Multifaceted Role of T-Helper Responses in Host Defense against Aspergillus fumigatus. J Fungi (Basel). 2017 Oct;3(4):55.

140 Millien VO, Lu W, Shaw J, Yuan X, Mak G, Roberts $\mathrm{L}$, et al. Cleavage of fibrinogen by proteinases elicits allergic responses through Toll-like receptor 4. Science. 2013 Aug; 341(6147):792-6.

141 Balenga NA, Klichinsky M, Xie Z, Chan EC, Zhao M, Jude J, et al. A fungal protease allergen provokes airway hyper-responsiveness in asthma. Nat Commun. 2015 Apr; 6(1):6763.

142 Carmona EM, Lamont JD, Xue A, Wylam M, Limper AH. Pneumocystis cell wall $\beta$-glucan stimulates calcium-dependent signaling of IL-8 secretion by human airway epithelial cells. Respir Res. 2010 Jul;11(1):95.

143 Neveu WA, Bernardo E, Allard JL, Nagaleekar V, Wargo MJ, Davis RJ, et al. Fungal allergen $\beta$-glucans trigger p38 mitogen-activated protein kinase-mediated IL- 6 translation in lung epithelial cells. Am J Respir Cell Mol Biol. 2011 Dec;45(6):1133-41.
144 Lee CG, Da Silva CA, Lee JY, Hartl D, Elias JA. Chitin regulation of immune responses: an old molecule with new roles. Curr Opin Immunol. 2008 Dec;20(6):684-9.

145 Reese TA, Liang HE, Tager AM, Luster AD, Van Rooijen N, Voehringer D, et al. Chitin induces accumulation in tissue of innate immune cells associated with allergy. Nature. 2007 May;447(7140):92-6.

146 Van Dyken SJ, Mohapatra A, Nussbaum JC, Molofsky AB, Thornton EE, Ziegler SF, et al. Chitin activates parallel immune modules that direct distinct inflammatory responses via innate lymphoid type 2 and $\gamma \delta$ T cells. Immunity. 2014 Mar;40(3):414-24.

147 Kita H. ILC2s and fungal allergy. Allergol Int. 2015 Jul;64(3):219-26.

148 Walker JA, McKenzie AN. Development and function of group 2 innate lymphoid cells. Curr Opin Immunol. 2013 Apr;25(2): 148-55.

149 Huang YJ, Marsland BJ, Bunyavanich S, O’Mahony L, Leung DY, Muraro A, et al. The microbiome in allergic disease: Current understanding and future opportunities-2017 PRACTALL document of the American Academy of Allergy, Asthma \& Immunology and the European Academy of Allergy and Clinical Immunology. J Allergy Clin Immunol. 2017 Apr;139(4):1099-110.

150 Chung H, Pamp SJ, Hill JA, Surana NK, Edelman SM, Troy EB, et al. Gut immune maturation depends on colonization with a host-specific microbiota. Cell. 2012 Jun; 149(7):1578-93.

151 Honda K, Littman DR. The microbiota in adaptive immune homeostasis and disease. Nature. 2016 Jul;535(7610):75-84.

152 Shibuya A, Shibuya K. Exploring the Gut Fungi-Lung Allergy Axis. Cell Host Microbe. 2018 Dec;24(6):755-7.

153 Underhill DM, Iliev ID. The mycobiota: interactions between commensal fungi and the host immune system. Nat Rev Immunol. 2014 Jun;14(6):405-16.

154 Wheeler ML, Limon JJ, Bar AS, Leal CA, Gargus M, Tang J, et al. Immunological consequences of intestinal fungal dysbiosis. Cell Host Microbe. 2016 Jun;19(6):865-73.

155 Noverr MC, Falkowski NR, McDonald RA, McKenzie AN, Huffnagle GB. Development of allergic airway disease in mice following antibiotic therapy and fungal microbiota increase: role of host genetics, antigen, and interleukin-13. Infect Immun. 2005 Jan;73(1): $30-8$.

156 Noverr MC, Noggle RM, Toews GB, Huffnagle GB. Role of antibiotics and fungal microbiota in driving pulmonary allergic responses. Infect Immun. 2004 Sep;72(9): 4996-5003.

157 Kim DH, Han K, Kim SW. Effects of antibiotics on the development of asthma and other allergic diseases in children and adolescents. Allergy Asthma Immunol Res. 2018 Sep;10(5):457-65. 
158 Reynolds LA, Finlay BB. A case for antibiotic perturbation of the microbiota leading to allergy development. Expert Rev Clin Immunol. 2013 Nov;9(11):1019-30.

159 Arrieta MC, Arévalo A, Stiemsma L, Dimitriu P, Chico ME, Loor S, et al. Associations between infant fungal and bacterial dysbiosis and childhood atopic wheeze in a nonindustrialized setting. J Allergy Clin Immunol. 2018 Aug;142(2):424-34.e10.

160 Ahmed I, Rabbi MB, Sultana S. Antibiotic resistance in Bangladesh: A systematic review. Int J Infect Dis. 2019 Mar;80:54-61.

161 Ayukekbong JA, Ntemgwa M, Atabe AN. The threat of antimicrobial resistance in developing countries: causes and control strategies. Antimicrob Resist Infect Control. 2017 May; 6(1):47.

162 Sokol H, Leducq V, Aschard H, Pham HP, Jegou S, Landman C, et al. Fungal microbiota dysbiosis in IBD. Gut. 2017 Jun;66(6): 1039-48.

163 Ott SJ, Kühbacher T, Musfeldt M, Rosenstiel P, Hellmig S, Rehman A, et al. Fungi and inflammatory bowel diseases: alterations of composition and diversity. Scand J Gastroenterol. 2008;43(7):831-41.

164 Hoarau G, Mukherjee PK, Gower-Rousseau C, Hager C, Chandra J, Retuerto MA, et al. Bacteriome and mycobiome interactions underscore microbial dysbiosis in familial Crohn's disease. MBio. 2016 Sep;7(5): e01250-01216.

165 Li Q, Wang C, Tang C, He Q, Li N, Li J. Dysbiosis of gut fungal microbiota is associated with mucosal inflammation in Crohn's disease. J Clin Gastroenterol. 2014 Jul;48(6): 513-23.

166 Strati F, Cavalieri D, Albanese D, De Felice C, Donati C, Hayek J, et al. New evidences on the altered gut microbiota in autism spectrum disorders. Microbiome. 2017 Feb;5(1): 24-24.

167 Strati F, Cavalieri D, Albanese D, De Felice C, Donati C, Hayek J, et al. Altered gut microbiota in Rett syndrome. Microbiome. 2016 Jul;4(1):41.

168 Benito-León J, Laurence M. The Role of Fungi in the Etiology of Multiple Sclerosis. Front Neurol. 2017 Oct;8:535.

169 Benito-León J, Pisa D, Alonso R, Calleja P, Díaz-Sánchez M, Carrasco L. Association between multiple sclerosis and Candida species: evidence from a case-control study. Eur J Clin Microbiol Infect Dis. 2010 Sep;29(9): 1139-45.

170 Robinson BW, Venaille TJ, Mendis AH, McAleer R. Allergens as proteases: an Aspergillus fumigatus proteinase directly induces human epithelial cell detachment. J Allergy Clin Immunol. 1990 Nov;86(5):726-31.

171 Templeton SP, Buskirk AD, Green BJ, Beezhold DH, Schmechel D. Murine models of airway fungal exposure and allergic sensitization. Med Mycol. 2010 Mar;48(2):217-28.

172 Matsuwaki Y, Wada K, White T, Moriyama $\mathrm{H}$, Kita $\mathrm{H}$. Alternaria fungus induces the production of GM-CSF, interleukin- 6 and interleukin-8 and calcium signaling in human airway epithelium through proteaseactivated receptor 2 . Int Arch Allergy Immunol. 2012;158(s1 Suppl 1):19-29.

173 Iijima K, Kobayashi T, Hara K, Kephart GM, Ziegler SF, McKenzie AN, et al. IL-33 and thymic stromal lymphopoietin mediate immune pathology in response to chronic airborne allergen exposure. J Immunol. 2014 Aug;193(4):1549-59.

174 Taube C, Dakhama A, Gelfand EW. Insights into the pathogenesis of asthma utilizing murine models. Int Arch Allergy Immunol. 2004 Oct;135(2):173-86.

175 Wenzel S, Holgate ST. The mouse trap: it still yields few answers in asthma. Am J Respir Crit Care Med. 2006 Dec;174(11):1173-6.

176 Pabst R. Animal models for asthma: controversial aspects and unsolved problems. Pathobiology. 2002-2003;70(5):252-4.

177 Epstein MM. Do mouse models of allergic asthma mimic clinical disease? Int Arch Allergy Immunol. 2004 Jan;133(1):84-100.

178 Takeda K, Gelfand EW. Mouse models of allergic diseases. Curr Opin Immunol. 2009 Dec;21(6):660-5.

179 Kips JC, Anderson GP, Fredberg JJ, Herz U, Inman $\mathrm{MD}$, Jordana $\mathrm{M}$, et al. Murine models of asthma. Eur Respir J. 2003 Aug;22(2): 374-82.

180 El-Gamal YM, Hossny EM, El-Sayed ZA, Reda SM. Allergy and immunology in Africa: challenges and unmet needs. J Allergy Clin Immunol. 2017 Nov; 140(5):1240-3.

181 Fujimura KE, Lynch SV. Microbiota in allergy and asthma and the emerging relation- ship with the gut microbiome. Cell Host Microbe. 2015 May; 17(5):592-602.

182 Papadopoulos NG, Agache I, Bavbek S, Bilo BM, Braido F, Cardona V, et al. Research needs in allergy: an EAACI position paper, in collaboration with EFA. Clin Transl Allergy. 2012 Nov;2(1):21.

183 Fujimura KE, Sitarik AR, Havstad S, Lin DL, Levan S, Fadrosh D, et al. Neonatal gut microbiota associates with childhood multisensitized atopy and $\mathrm{T}$ cell differentiation. Nat Med. 2016 Oct;22(10):1187-91.

184 Arrieta MC, Arévalo A, Stiemsma L, Dimitriu P, Chico ME, Loor S, et al. Associations between infant fungal and bacterial dysbiosis and childhood atopic wheeze in a nonindustrialized setting. J Allergy Clin Immunol. 2018 Aug;142(2):424-34.e10.

185 Rajan TV. The Gell-Coombs classification of hypersensitivity reactions: a re-interpretation. Trends Immunol. $2003 \mathrm{Jul} ; 24(7)$ : $376-9$

186 Liu YJ. Thymic stromal lymphopoietin: master switch for allergic inflammation. J Exp Med. 2006 Feb;203(2):269-73.

187 Liu YJ. Thymic stromal lymphopoietin and OX40 ligand pathway in the initiation of dendritic cell-mediated allergic inflammation. J Allergy Clin Immunol. 2007 Aug; 120(2):238-44.

188 Murrison LB, Brandt EB, Myers JB, Hershey GK. Environmental exposures and mechanisms in allergy and asthma development. J Clin Invest. 2019 Apr;129(4):1504-15.

189 Zhou X, Loomis-King H, Gurczynski SJ, Wilke CA, Konopka KE, Ptaschinski C, et al. Bone marrow transplantation alters lung antigen-presenting cells to promote $\mathrm{TH} 17$ response and the development of pneumonitis and fibrosis following gammaherpesvirus infection. Mucosal Immunol. 2016 May; 9(3):610-20.

190 Peters M, Köhler-Bachmann S, Lenz-Habijan T, Bufe A. Influence of an allergen-specific Th17 response on remodeling of the airways. Am J Respir Cell Mol Biol. 2016 Mar;54(3):350-8.

191 Xia W, Bai J, Wu X, Wei Y, Feng S, Li L, et al. Interleukin-17A promotes MUC5AC expression and goblet cell hyperplasia in nasal polyps via the Act1-mediated pathway. PLoS One. 2014 Jun;9(6):e98915.
Pathogenesis of Immune-Mediated Fungal Diseases in Africa
Int Arch Allergy Immunol 2020;181:257-269 DOI: $10.1159 / 000506009$ 